Volume 9, No.1, January - February 2020

International Journal of Advanced Trends in Computer Science and Engineering

Available Online at http://www.warse.org/IJATCSE/static/pdf/file/ijatcse41912020.pdf

https://doi.org/10.30534/ijatcse/2020/41912020

\title{
Strategic Planning of Information Systems in a Timber Company
}

\author{
Sfenrianto $^{1}$, Muhammad Jibril ${ }^{2}$, Kaman Nainggolan ${ }^{3}$, Viany Utami Tjhin ${ }^{4}$ \\ ${ }^{124}$ Information Systems Management Department, BINUS Graduate Program - Master of Information Systems \\ Management, Bina Nusantara University, Jakarta 11480 \\ ${ }^{3}$ School of Information Management and Computer, STMIK Nusa Mandiri, Jakarta Indonesia \\ ${ }^{1}$ sfenrianto@binus.edu, ${ }^{2}$ kuliah.jibril@gmail.com, ${ }^{3}$ golan1251@yahoo.co.id, ${ }^{4}$ vtjhin@ @inus.edu
}

\begin{abstract}
Strategic Planning of Information Systems is needed by timber companies to align business strategy and information systems strategy. In Indonesia, the integrated timber industry had implemented information systems management in the field of sustainable forest management. Existing information systems developed by IT departments that exist in the company. However, the development of information systems does not have the information systems strategic planning in IT departments. The system development processes no priority system what information should be done. Therefore, it is necessary to make strategic planning of information systems to support and assist the IT team in the process of system development. This study discussed information systems strategic plans using the framework Ward \& Peppard. It conducted an internal and external analysis of IS/IT. For the analysis of the company's internal and external analysis need not be performed but was replaced with the existing strategy in the company. Based on this analysis will produce IS strategy, IT strategy, and management strategies in IS/IT.
\end{abstract}

Key words: Strategic Planning, Ward \& Peppard, information systems, timber company, business strategy, IS strategy

\section{INTRODUCTION}

In the era of information system development, the role of information systems is necessary for the company. It does not only serve as supporting activities in business but also as the means of a mainstay in increasing productivity. Information systems used to achieve the vision and mission of the company [1]. A strategic plan is capable of being used as a powerful tool [2][3]. Then, an enterprise used information systems to maintain the company's position and increase its competitive advantage.
A company considered achieving a competitive advantage. The company has reached one or more of its business goals, especially in operational excellence, customer relations, and improving the quality of decision making [4]. The enterprise should do something better than a competitor that cannot be followed by those competitors. One way to achieve using information systems to achieve their objectives.

In Indonesia, the timber companies are engaged in the industrial exploitation of the forest and wood processing integrated that has evolved over more than 40 years. The company developed the information systems that have been independently developed by parties for the operation of internal corporate transactions, such as for logistics and finance needs.

. However, the IT team at the company does not have a strategic planning system currently so that the information system developments have no priority system what information should be provided. Therefore, it is necessary to make strategic planning of information systems to support and assist the IT team in the process of system development. Research conducted Timber Company in Indonesia. This research aims to align the strategic planning of information systems with its business strategy.

\section{LITERATURE REVIEW}

Research conducted in [5], discusses the benefits of investment SI / IT is running (Lights-on) and project application system on PT Nuance Aspiration in Jakarta. The study uses a framework of New Information Economics (NIE). This study discussed investment SI / IT that aligned with the direction of corporate strategy and whether costs incurred in proportion to the benefits and positive impact on bottom-line. The final results of these studies required the development and progression of various applications, infrastructure, services, and management of lights-on to achieve and maintain the strategic direction of the company. 
The other studies [3] discussed the strategic information systems in the case of integrated Islamic school Salman Alfarasi in Yogyakarta. The study mentions that if able to use information systems to the maximum can achieve a competitive advantage. Ward \& Peppard combination framework and Enterprise Architecture Planning a reference in the study and analysis tool used is the value chain, PEST, SWOT, and McFarland Strategic Grid.

Haron \& Zolkarnain emphasized that strategic information systems can increase the competitive advantage of a business entity, in this case of Small and Medium Enterprise (SME) in Malaysia [6]. The study focused on strategic information systems and information systems portfolio recommendations. These studies used Framework Ward \& Peppard and used for the analysis is the value chain and Porter's five forces. The study focused on exploratory studies in the field of strategic information systems that can enhance the competitive advantage of SMEs in Malaysia.

The other study discussed the strategic information systems with case studies in the office of women's empowerment and family planning in the district Anambas [6]. The study stated that there are still many activities carried conventional consequently cannot support the achievement of targets and optimal performance if the information systems have not been fully implemented. The study uses a framework, Ward and Peppard. The analysis tool used is PEST, CSF, SWOT, Value Chain, and McFarlan Strategic Grid. The result of this research is the strategic planning of information systems in the future.

Chandra stressed that to enhance the competitive advantage necessary strategic business plan and the strategic plan of information systems in case studies Nusa Nipa University in the province of East Nusa Tenggara [7]. The study used a framework, Ward and Peppard. The analysis tool used is PEST, CSF, SWOT, Porter, Value Chain, and McFarlan Strategic Grid. This research resulted in IS/IT strategic planning as a guideline for management in determining the development and management of IS / IT in UNIPA.

The strategy comes from the Greek, the "strategia," which means the general or joint. Strategy based initially on the military, which then developed to cover the scope of deploying. Strategy becomes a method for connecting between the current situation with the ultimate goal to be achieved [9]. Information Systems Strategic Planning is a strategic planning process undertaken an organization to determine the strategy or direction, and making decisions to allocate resources (including capital and human resources) to achieve a predetermined plan and identify strategic business and to align an information system strategy [10].

\section{RESEARCH METHOD}

The framework used in this study was Ward \& Peppard. Figure 1 shows these frameworks. The explanation of the steps to be taken in the preparation of the strategic planning of information systems is as follows:

1. Accomplish part of the company's internal and external analysis of the company and a corporate strategy.

2. Conduct external analysis of information systems and external assessment to get the viewpoint of related companies SI and new technologies trends that are happening today. The data obtained in this analysis of technology trends that exist today. Technology trends derived from the observation of the writer and literature studies.

3. Conduct analysis of internal SI internal analysis conducted aimed at identifying the internal conditions of the SI in the form of an information system used today, IT asset and network infrastructure companies. The data obtained from interviews. This study conducted interviews with SIMPH, who knew very well about the information systems in use today.

4. Define Information Systems Strategy for the need for an information system to support the entire process of firms that exist within the company in the form of information systems. The recommended information system should be capable of supporting the whole operations within the company. This study resulted in the information system strategy that proposed information systems or information systems along with a roadmap on information systems. It will be developed within the company so that it can help the company to gain a competitive advantage or a means for companies to achieve the vision and mission which has arranged.

5. Assign Information Technology Strategy to determine the information systems supported by information technology in meeting the needs of information. Results of this information technology strategy in the form of suggestions and proposals computer network hardware to support information systems strategy that had proposed previously.

6. The IT management strategy is useful to formulate the human resources which meet and support the strategy of IS / IT, which proposed previously. 


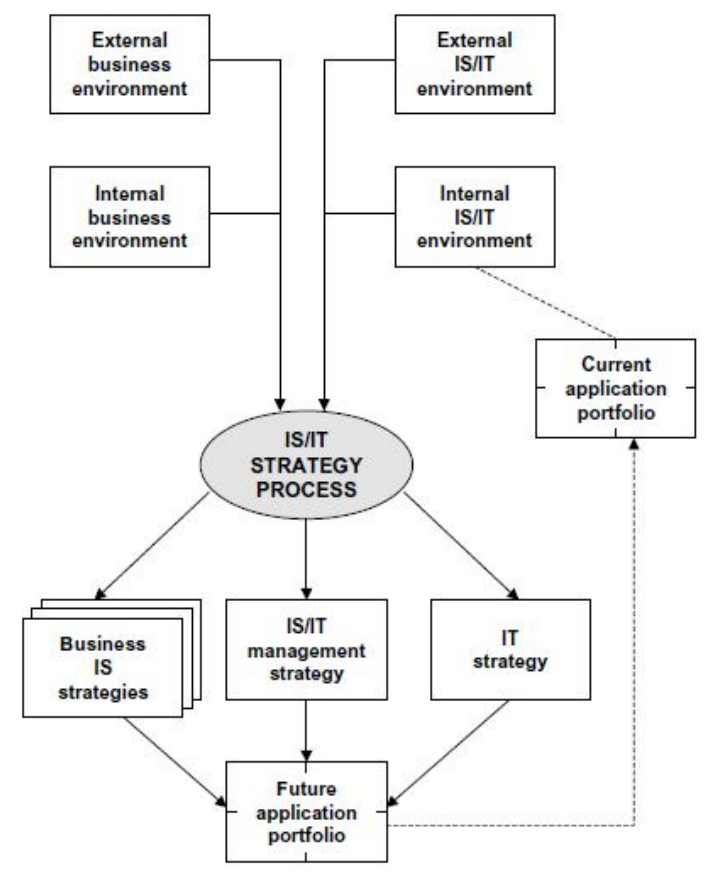

Figure 1: Framework Ward \& Peppard [10]

\section{ANALYSIS AND DISCUSSION}

\subsection{Company Profile and Strategy}

The study carried out on the Timber Company Indonesia is a company engaged in the field of Timber Forest Product Utilization of Natural Forest, which began operating in 1973. The management of committed to sustainable forest management by not only see the production aspect only consider this but also information system aspects as well as the environment that is around.

The strategy of the company needs the information system for the use of wood-based forest products environmentally-friendly (or reduced impact logging), namely: (1) forest planning, (2) forest opening activities; (3) Procurement of seedlings, planting, and maintenance of plants, (4) harvesting activities, and (5) activities carried out during the post-harvest.

Forest Planning strategy namely: (1) creating boundaries of the work area and work area activities arrangement consists of make appointment boundaries bracelet, creating a block boundary CTR, create working plot boundaries, creating a boundary subplot work, and create a buffer zone; (2) make an inventory of stands before logging activities consist of survey topography (contour), a survey of trees (tree distribution map); and (3) Rill survey included determining the location of landings, making the skid trail plan.
The second strategy is forest opening activities. The activities undertaken at this stage are : (1) making the bridge by standard procedures such as streams that are not clogged by garbage timber and other materials; (2) road maintenance Logging roads in regularly maintained to be able to reduce the soil erosion; and (3) The opening of skid trails and landings.

The next strategy is the procurement of seedlings, planting, and maintenance of plants. Then, harvesting activities carried out at the time of harvesting, namely: logging, skidding, and Post-Harvesting. The end strategy is activities carried out during the post-harvest: (1) overlays the topsoil on the former TPN, (2) deactivation of roads and diversion, (c) the process of grading and marking Log, and (3) The process of loading the result of logging onto barges.

\subsection{Analysis of External Environment IS / IT}

Analysis of the external environment / IT is based on current technology trends. Based on current trends, this study's observations associated with today's technology are the smartphone. Nowadays, almost everyone has a smartphone. The smartphones are not only used as a means of communication (such as telephone and SMS). It also has been equipped with a variety of exciting features and specifications).

In the corporate environment today from observations, each person has more than one smartphone. According to kominfo.go.id, smartphone users in Indonesia increased rapidly in 2018. The number of active smartphone users in Indonesia has reached more than 100 million people. Therefore, the author will use the smartphone phenomenon for the strategic planning of information systems in the enterprise. By utilizing the smartphone, the authors plan to propose the making of web-based information systems in the company mobile.

The system aimed to support users who often work outside the office. Those who usually work outside the office cannot always be in front of their laptops or computers. So, to make it easier for the user in the daily works, the researcher would like to propose the mobile web.

\subsection{Analysis of Internal Environment IS / IT}

This stage focused on the analysis of the internal environment and the information systems, which implemented in the company. This stage started from the portfolio of applications to network infrastructure conditions used in the company. The current applications: logistics information system, a system of accounting and finance information, the cost and budgeting, and human resource information system. 


\subsection{IS Strategy, IT Strategy, and Management Strategy IS / IT}

To support the strategic planning of IS/IT work well, it needs an IS strategy, IT Strategy, and management strategy IS or IT. Table 1 showed about information system strategy, which proposed in this study. There are four proposed strategies, namely, strategic, high potential, key operation, and support. Each strategy is expected to support Information Systems in a Timber Company Indonesia.

Table 1: IS Strategy Proposed

\begin{tabular}{|c|l|}
\hline IS Strategy & \multicolumn{1}{|c|}{ Proposed } \\
\hline Strategic & $\begin{array}{l}\text { Geographic Information } \\
\text { Systems }\end{array}$ \\
\cline { 2 - 2 } & $\begin{array}{l}\text { Production Information } \\
\text { Systems }\end{array}$ \\
\hline $\begin{array}{c}\text { High } \\
\text { Potential }\end{array}$ & $\begin{array}{l}\text { Enterprise Resource } \\
\text { Planning (ERP) }\end{array}$ \\
\hline Key \\
Operation & $\begin{array}{l}\text { Logistics Information } \\
\text { System }\end{array}$ \\
\cline { 2 - 2 } & $\begin{array}{l}\text { Information Systems } \\
\text { Accounting \& Finance }\end{array}$ \\
\cline { 2 - 3 } & Human Resource \\
\hline Support & $\begin{array}{l}\text { Knowledge Management } \\
\text { System (KMS) }\end{array}$ \\
\hline
\end{tabular}

For the IT strategy, the company currently has the server to support information systems that already exist today. The time speed internet access in the company still feels especially when working hours because it is only $512 \mathrm{Kbps}$ of bandwidth, server mirroring for data backup process does not exist, and development servers did not exist as well. It is necessary to increase internet bandwidth to speed up Internet connections at $5 \mathrm{MBps}$, adding servers to support the data backup process and improve the development process to use the IS/ IT.

To support the strategic planning of IS/IT work well, it also needs a management strategy or IT solution according to the proposed one. The application of IS/IT is no need to be supported human resources who are experts in the IT field. With the implementation of new technology and competent human resources will improve the effectiveness and efficiency of business processes in the company. Following the proposal of human resources required to support the solution of IS/IT to be applied. Table 2 showed about information system strategy, which proposed in this study.
Table 2: A Proposed for Management Strategy IS/IT

\begin{tabular}{|l|c|}
\hline \multicolumn{1}{|c|}{ Strategic } & $\begin{array}{c}\text { Number of } \\
\text { Needs }\end{array}$ \\
\hline $\begin{array}{l}\text { System Analyst } \\
\text { Programmer }\end{array}$ & 2 \\
\hline Quality Assurance & 4 \\
\hline System Analyst & 2 \\
\hline Programmer & 3 \\
\hline
\end{tabular}

\section{CONCLUSION}

From the analysis and discussion of the strategic planning of IS / IT in companies using the framework Ward \& Peppard, this study concludes as follows: (1) Strategy system-generated information is in the form of the proposed reports. (2) Strategic information technology hardware produced the proposed network of infrastructure. (3) The strategic management system had generated information in the form of proposals or recommendations to support the human resources information system strategy that has been proposed.

\section{REFERENCES}

1. A. Setiawan, \& E. Yulianto. (2017). Information System Strategic Planning Using IT Balanced Scorecard In Ward \& Peppard Framework Model. International Journal of Engineering and Technology (IJET). p1864-1872. https://doi.org/10.21817/ijet/2017/v9i3/170903134

2. S. Allahawiah, S. Altarawneh, \& A. Altarawneh. (2019). The Utilization of Education Management Information System (EMIS) to Predict Future Maintenance Plans for Buildings: A Case Study of Karak Governorate Schools. International Journal of Advanced Trends in Computer Science and Engineering, vol. 8(5) pp. 2495-2506. https://doi.org/10.30534/ijatcse/2019/95852019

3. I. S. Widiati, E. Utami, \& H. Henderi. (2015). Perencanaan Strategis Sistem Informasi Untuk Meningkatkan Keunggulan Kompetitif Sekolah Islam Terpadu. Creative Information Technology Journal, vol.2(4), pp. 329-340.

4. K.C. Laudon, \& J. P. Laudon. Essentials of management information systems. Upper Saddle River: Pearson, 2011

5. Hudiarto, E. A. Kuncoro, Halim, \& Merry. Analisis Investasi Sistem Aplikasi yang Berjalan dan Proyek Sistem Informasi menggunakan Metode New Information Economics pada Adandu (PT. Nuansa Aspirasi Bening, Jakarta). Prosiding Seminar Nasional Manajemen Teknologi XIV, ITS, 2011.

6. H. Haron, S. M. Sabri, \& Z. N. Zolkarnain, (2013, November). A situational analysis of strategic information system planning in the context of a Malaysian SME. In 2013 International Conference on 
Research and Innovation in Information Systems (ICRIIS) (pp. 539-543). IEEE.

https://doi.org/10.1109/ICRIIS.2013.6716766

7. V. M. Kawangung, I. Wisnubhadra, \& K. Anindito, (2014). Perencanaan Strategis Sistem Informasi (Studi Kasus di Kantor Pemberdayaan Perempuan dan Keluarga Berencana). Prosiding Seminar Nasional Multi Disiplin Ilmu \& Call for Papers UNISBANK.

8. C. J. Chandra. (2016). Perencanaan Strategis Sistem Informasi dan Teknologi Informasi Menggunakan Metode Ward dan Peppard. Seminar Nasional Teknologi Informasi dan Komunikasi (SENTIKA 2016), Universitas Atma Jaya Yogyakarta, Yogyakarta, 18-19 Maret 2016.

9. A. Bonyadi, F. R. Nikou, \& S. Shahbaz, S., 2012. The relationship between EFL learners' self-efficacy beliefs and their language learning strategy Use. English Language Teaching, 5(8), pp.113-121. https://doi.org/10.5539/elt.v5n8p113

10. Al-Aomar, R., \& Al-Meer, H. (2012). Quality Function Deployment for Service: A Case Study of Enhancing the Planning Statement of a Utility Company. International Journal of Advanced Trends in Computer Science and Engineering, vol. 1(4), pp 113-120 